\title{
ISO 9001 STANDARD MANAGEMENT SYSTEM CERTIFICATION - DATA ANALYSIS FOR SECTORS BY COUNTRY
}

\author{
doi: 10.2478/cqpi-2019-0022 \\ Date of submission of the article to the Editor: 04/03/2019 \\ Date of acceptance of the article by the Editor: 08/05/2019
}

Katarzyna Hys ${ }^{1}$ - orcid id: 0000-0003-0800-2804

1 Opole University of Technology Poland

\begin{abstract}
The purpose of the paper is to analyse and demonstrate the trends in the scope of data concerning the number of ISO 9001 certificates incorporated in companies around the world with consideration of market division into 39 sectors. The study utilised the desk research method for analysing the available sources of data for the studied problem, especially covering their compilation, mutual verification, processing and reasoning. Then, multi-dimensional comparative analyses were conducted for the obtained results within a time framework of 1998-2017. As result of the conducted analyses, leading sectors in particular countries in terms of the number of incorporated ISO 9001 series standards were established. This enabled identifying the tendencies and determining the further directions of change. The paper is original in that it is based on analysing data within an industry framework in the period of nine years, identifying existing trends and establishing specific cases (countries and industries) for which the ISO 9001 standards are common and for which they are a niche.
\end{abstract}

Keywords: ISO 9001, certifications, sectors by country

\section{INTRODUCTION}

The ISO 9001 international standard has permanently taken root in enterprises all across the world (Heras-Saizarbitoria, 2011; Koc, 2007; Marin et al., 2011). It became an inseparable system element of many organisations and it seems that classifying it as a component of organisational culture has its rational justification (Kim et al., 2011; Briscoe et al., 2005). ISO 9001 constitutes a widely recognised quality management standard in terms of planning, organising, monitoring and control in the framework of continuous improvement (Allur et al., 2014; Franceschini et al., 2018). Regardless of the deficiencies of the normative approach to a company's quality management system, as of yet only the ISO 9001 standard was spread on a global scale (Rusjan et al., 2010, Sampaio et al., 2009). Naturally, the intensity of incorporating the ISO 9001 in companies across the world varies, because it depends on many external and internal factors (Sampaio et al., 2009, Terziovski et al., 2003). Nevertheless, an analysis of the statistics concerning the number of ISO 9001 incorporations in companies of a given 
country allows for the observation of a dependency between the number and the given country's degree of economic growth, political and legal, technical and technological, social and cultural or international dimension (Hys, 2015, Dick et al., 2008).

\section{METHODOLOGY OF RESEARCH}

The purpose of the paper is to analyse and demonstrate the trends in the scope of data concerning the number of ISO 9001 certificates incorporated in companies around the world with consideration of market division into 39 sectors. The study was conducted using the desk research method. The data was organised according to an established selection key resulting from the adopted detailed objectives of this paper. The analysis covered over a dozen reports published by the International Organization for Standardization, an independent, non-governmental international organisation with a membership of 162 national standards bodies. Accredited bodies from nearly all countries in the world annually submit current statistical data on the number of ISO 9001 certificates obtained by companies in the given year. Thanks to a co-operation with these bodies, International Organization for Standardization keeps a regular list and thus monitoring of the changes in the scope of ISO 9001 incorporations. This paper will be focused on ISO 9001 incorporations, but from the perspective of industry sectors (Table 1). All sectors were classified in 39 groups, which results from the adopted European classification (EA stands for European Accreditation). The data analysis was conducted for the period between 1998 to 2017.

Table 1

EA stands for European Accreditation

\begin{tabular}{|c|l|c|l|}
\hline $\begin{array}{c}\text { EA } \\
\text { CODE }\end{array}$ & \multicolumn{1}{|c|}{$\begin{array}{c}\text { EA DESCRIPTION, } \\
\text { INDUSTRY }\end{array}$} & $\begin{array}{c}\text { EA } \\
\text { CODE }\end{array}$ & \multicolumn{1}{|c|}{ EA DESCRIPTION, INDUSTRY } \\
\hline 1 & Agriculture \& Fishing & 21 & Aerospace \\
\hline 2 & Mining \& Quarrying & 22 & Other Transport Equipment \\
\hline 3 & $\begin{array}{l}\text { Food products, Beverages \& } \\
\text { Tobacco }\end{array}$ & 23 & $\begin{array}{l}\text { Manufacturing (not elsewhere } \\
\text { classified) }\end{array}$ \\
\hline 4 & Textiles \& Textile Products & 24 & Recycling \\
\hline 5 & Leather \& Leather Products & 25 & Electricity Supply \\
\hline 6 & Wood \& Wood Products & 26 & Gas Supply \\
\hline 7 & Pulp, Paper \& Paper Products & 27 & Water Supply \\
\hline 8 & Publishing Companies & 28 & Construction \\
\hline 9 & Printing Companies & 29 & $\begin{array}{l}\text { Wholesale \& Retail Trade; Repair of } \\
\text { Motor Vehicles, Motorcycles }\end{array}$ \\
\hline 10 & Manufacture of Coke \& Refined & 30 & Hotels \& Restaurants \\
\hline 11 & Netroleum Products & 31 & Transport, Storage \& Communication \\
\hline 12 & $\begin{array}{l}\text { Chemicals, Chemical Products } \\
\text { \& Fibres }\end{array}$ & 32 & $\begin{array}{l}\text { Financial Intermediation; Real Estate \& } \\
\text { Renting }\end{array}$ \\
\hline 13 & Pharmaceuticals & 33 & Information Technology \\
\hline 14 & Rubber \& Plastic Products & 34 & Engineering Services \\
\hline 15 & Non-Metallic Mineral Products & 35 & Other Services \\
\hline 16 & $\begin{array}{l}\text { Concrete, Cement, Lime, } \\
\text { Plaster }\end{array}$ & 36 & Public Administration \\
\hline 17 & $\begin{array}{l}\text { Basic Metals \& Fabricated } \\
\text { Metal Products }\end{array}$ & 37 & Education \\
\hline 18 & Machinery \& Equipment & 38 & Health \& Social Work \\
\hline
\end{tabular}




\begin{tabular}{|l|l|c|l|}
\hline 19 & Electrical \& Optical Equipment & \multirow{2}{*}{39} & Other Social Services \\
\hline 20 & Shipbuilding & & \\
\hline
\end{tabular}

The data analysis was conducted in the scope of detailed objectives conforming to the paper's main objective, specifically:

P1: global data analysis in the scope of 162 countries, the accredited bodies of which are International Organization for Standardization members.

P2: data analysis concerning the number of ISO 9001 incorporations for particular sectors in European countries.

P3: data analysis concerning the number of global incorporations in particular years for sectors that are leading or incidentally take part in ISO 9001 incorporations.

\section{RESULTS}

The realisation of the detailed objectives allowed for analysing the statistical data in the scope of ISO 9001 incorporation intensity in the world, with specific consideration of industrial sectors. The data analysis was conducted in three stages: in the scope of global data; data concerning the ISO 9001 incorporations in 39 sectors in European countries and the analysis of leading and incidental sectors for these countries.

\subsection{ISO 9001 by industrial sector in the world}

The global data analysis period covered 20 years, starting in 1998. It is a period during which accredited certification bodies being ISO members submitted data on the incorporation numbers as part of co-operation. The number of ISO 9001 incorporations for 39 industry sectors for the given period constitutes impressive analytical material. The breakdown of data in a global framework (the data concerns all countries submitting data to the ISO) allows for the following interpretation. A general breakdown, due to the data's multiplicity, is rather indecipherable (Fig. 1).

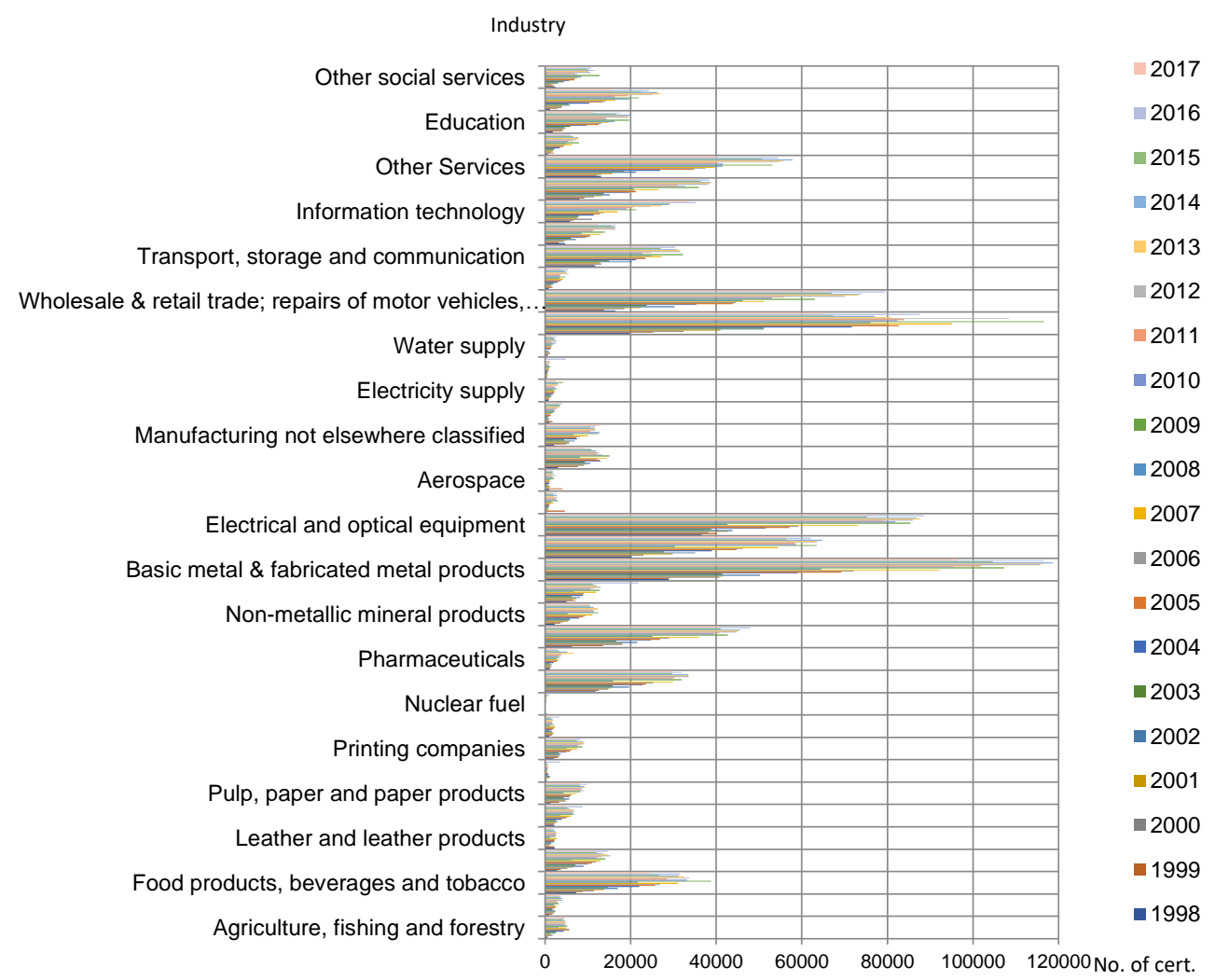

Fig. 1. ISO 9001 by industrial sector in the world (1998-2017) 
Source: own study based on (The ISO Survey 1998-2017, Switzerland, 2018)

On the other hand however, it allows isolating sectors for which the ISO 9001 incorporation is executed in an incidental and widespread manners.

A review of general data concerning the number of ISO 9001 incorporations, in terms of sector assignment, allowed for isolating the sectors for which the ISO 9001 incorporation is executed globally in a widespread and incidental manner.

The industry sectors that feature widespread incorporations in the global scale are as follows: Basic Metals \& Fabricated Metal Products; Construction; Electrical \& Optical Equipment; Wholesale \& Retail Trade; Repair of Motor Vehicles; Motorcycles \& Personal \& Household Goods; Machinery \& Equipment; Other Services and Rubber \& Plastic Products. On the other hand, the sectors in which the ISO 9001 incorporations are incidental include, among others, the following: Nuclear Fuel; Publishing Companies; Gas Supply; Water Supply; Manufacture of Coke \& Refined Petroleum Products; Aerospace and Shipbuilding.

\subsection{ISO 9001 by industrial sector in the Europe}

In terms of the data quantity, the subsequent analysis was spatially limited and only covered European countries. Due to the lack of data for the Vatican and Macedonia, 44 out of 46 European countries were analysed. Moreover, in 2009 there was also no data available for Luxembourg. An extended data analysis was conducted in the next stage. The issue concerned analysing and comparing the data in terms of leading and incidental sectors. It was interesting to verify whether global data concerning the number of ISO 9001 incorporations for particular industrial sectors will be reflected in the number for Europe (Fig. 2).

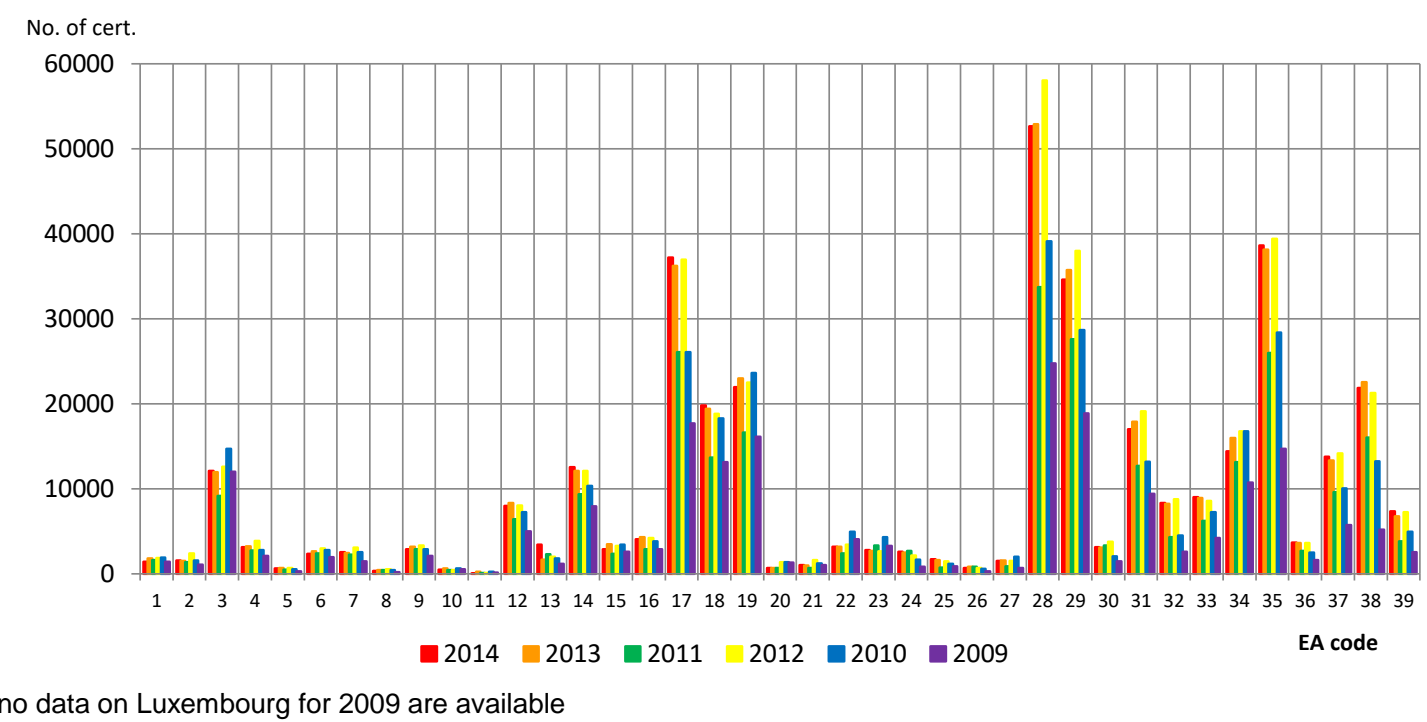

Fig. 2. ISO 9001 by industrial sector in the Europe (2009-2015)

Source: own study based on (The ISO Survey 1998-2017, Switzerland, 2018)

In European countries, the most common ISO 9001 incorporations are executed in the following sectors: Construction; Wholesale \& Retail Trade, Repair of Motor Vehicles; Motorcycles \& Personal \& Household Goods; Other Services; Basic Metals \& Fabricated Metal Products; Electrical \& Optical Equipment and Health \& Social Work. On the other hand, the least ISO 9001 incorporations was recorded in such sectors as: 
Nuclear Fuel; Publishing Companies; Manufacture of Coke \& Refined Petroleum Products; Leather \& Leather Products and Gas Supply.

\subsection{ISO 9001 according to the industrial sector in the world - detailed data}

The analysis of particular sectors demonstrated that the industry that most often incorporates the ISO 9001 globally is Construction, whereas the least often - Nuclear fuel (Table 2). For researchers dealing in particular sectors and their evolution in terms of developing and implementing the ISO 9001 standard, the data specified in Table 2 provide detailed information on the number of the standard's incorporations.

Table 2

ISO 9001 the number of the standard's incorporations by sectors

\begin{tabular}{|c|c|c|c|c|c|c|c|c|c|c|}
\hline A CODE & 1998 & 1999 & 2000 & 2001 & 2002 & 2003 & 2004 & 2005 & 2006 & 2007 \\
\hline 1 & 610 & 678 & 1745 & 1265 & 2381 & & & 797 & & \\
\hline 2 & 1052 & 1791 & 2028 & 2359 & 2423 & 1758 & 1801 & 436 & 508 & \\
\hline 3 & 7347 & 8746 & 11440 & 13805 & 17038 & 14682 & 2203 & 2573 & 2687 & 10 \\
\hline 4 & 2835 & 3673 & 5178 & 6706 & 9071 & 7151 & $101 \overline{3}$ & $110 \overline{2}$ & $118 \overline{9}$ & \\
\hline 5 & 2313 & 2093 & 926 & 1063 & 1490 & 1394 & 2118 & 2252 & $235 \overline{0}$ & \\
\hline 6 & 2218 & 1967 & 2225 & 2791 & 2910 & 2483 & 3971 & 4824 & 5196 & 13 \\
\hline 7 & 1316 & 3279 & 4785 & 4961 & 5693 & 4375 & 5674 & 5929 & 6218 & \\
\hline 8 & 363 & 354 & 445 & 1048 & 1212 & 617 & 844 & 697 & 608 & \\
\hline 9 & 1998 & 2939 & 3299 & 3191 & 3630 & 3234 & 4965 & 5808 & 6168 & 151 \\
\hline 10 & 1009 & 1669 & 1929 & 1927 & 1620 & 1052 & 614 & 2072 & 2199 & \\
\hline $11 \mathrm{Nucl}$ & 279 & 220 & 115 & 96 & 192 & 68 & 69 & 131 & 167 & \\
\hline 12 & 11803 & 12615 & 14790 & 15505 & 19612 & 15806 & 2291 & 2368 & 2530 & \\
\hline 13 & 1160 & 1105 & 1451 & 1349 & 1697 & 1160 & 1943 & $5 \overline{7}$ & $306 \hat{1}$ & \\
\hline 14 & 6277 & 13575 & 18036 & 18243 & 21517 & 16683 & 2472 & 2694 & 2898 & \\
\hline 15 & 2328 & 3571 & 4209 & 5363 & 5753 & 5847 & $797 \overline{7}$ & $897 \overline{3}$ & $948 \overline{2}$ & 11 \\
\hline 16 & 4998 & 7107 & 6467 & 7290 & 8218 & 6217 & 8812 & 8956 & 9142 & \\
\hline 17 & 28885 & 28972 & 40713 & 41534 & 50234 & 41455 & 5904 & 6919 & 7210 & \\
\hline 18 & 20275 & 19827 & 23027 & 29812 & 35047 & 27705 & $390 \overline{2}$ & $447 \overline{8}$ & $462 \overline{9}$ & \\
\hline 19 & 36653 & 40035 & 38148 & 42710 & 43839 & 38782 & $516 \hat{2}$ & $571 \overline{6}$ & $591 \hat{3}$ & \\
\hline 20 & 398 & 4670 & 589 & 881 & 689 & 984 & $97 \overline{2}$ & 1030 & 1192 & 19 \\
\hline 21 & 1052 & 4131 & 924 & 1314 & 866 & 606 & 1025 & 967 & 1161 & \\
\hline 22 & 3040 & 7656 & 9072 & 9573 & 10561 & 9311 & 1299 & 1273 & 1213 & \\
\hline 23 & 2106 & 4844 & 5534 & 5680 & 6914 & 4535 & $7500^{-}$ & 7293 & $818 \overline{8}$ & 10 \\
\hline 24 & 1001 & 1765 & 932 & 959 & 966 & 580 & 989 & 1445 & 1199 & 4 \\
\hline 25 & 860 & 932 & 979 & 1349 & 1503 & 1190 & 1887 & 2163 & 2251 & 23 \\
\hline 26 & 390 & 558 & 531 & 664 & 584 & 559 & 658 & 863 & 975 & \\
\hline 27 & 505 & 799 & 1242 & 932 & 874 & 138 & 1136 & 1404 & 1525 & \\
\hline 28 & 19768 & 25273 & 32389 & 40948 & 51093 & 51188 & 7165 & 8266 & 8043 & \\
\hline 29 & 16451 & 13803 & 18530 & 22385 & 30280 & 23751 & $353 \overline{8}$ & $439 \overline{7}$ & $446 \overline{2}$ & \\
\hline 30 & 865 & 1794 & 1187 & 1500 & 1840 & 2245 & 2924 & 3557 & $387 \overline{5}$ & \\
\hline
\end{tabular}


Table 2

ISO 9001 the number of the standard's incorporations by sectors cont.

\begin{tabular}{lrrrrrrrrrr} 
EA CODE & $\mathbf{1 9 9 8}$ & $\mathbf{1 9 9 9}$ & $\mathbf{2 0 0 0}$ & $\mathbf{2 0 0 1}$ & $\mathbf{2 0 0 2}$ & $\mathbf{2 0 0 3}$ & $\mathbf{2 0 0 4}$ & $\mathbf{2 0 0 5}$ & $\mathbf{2 0 0 6}$ & $\mathbf{2 0 0 7}$ \\
31 & 11738 & 11366 & 13181 & 12732 & 20356 & 14955 & 21265 & 23520 & 23372 & 27202 \\
32 & 4690 & 3218 & 4367 & 4950 & 7195 & 6149 & 9559 & 10452 & 10604 & 13008 \\
33 & 5826 & 6706 & 11067 & 7529 & 7777 & 7906 & 11412 & 12785 & 13674 & 16962 \\
34 & 8064 & 9201 & 11451 & 13303 & 15089 & 13738 & 19657 & 21277 & 20969 & 26683 \\
35 & 13088 & 12150 & 13160 & 15762 & 21270 & 18379 & 26954 & 34825 & 37507 & 39657 \\
36 & 689 & 2086 & 1404 & 1840 & 1932 & 2229 & 3457 & 4213 & 4371 & 6208 \\
37 & 1833 & 3996 & 4282 & 4879 & 4544 & 5915 & 9625 & 12607 & 13200 & 14832 \\
38 & 1250 & 2871 & 3820 & 4010 & 5807 & 5561 & 10295 & 13389 & 14180 & 16516 \\
39 & 2513 & 2005 & 1529 & 2372 & 3111 & 4413 & 5657 & 6817 & 7073 & 7750 \\
\hline Total & $\mathbf{2 2 9 8 4}$ & $\mathbf{2 7 4 0 4 0}$ & $\mathbf{3 1 7 1 2}$ & $\mathbf{3 5 4 5 8}$ & $\mathbf{4 2 6 8 2}$ & $\mathbf{3 6 7 3 8}$ & $\mathbf{5 2 8 6 3}$ & $\mathbf{6 0 7 1 4}$ & $\mathbf{6 2 5 7 4}$ & $\mathbf{7 4 3 1 4}$ \\
Source: (The ISO Survey $\mathbf{1 9 9 8}-2017$, & Switzerland, 2018) & & & &
\end{tabular}

Table 2

ISO 9001 the number of the standard's incorporations by sectors cont.

\begin{tabular}{|c|c|c|c|c|c|c|c|c|c|c|}
\hline EA CODE & 2008 & 2009 & 2010 & 2011 & 2012 & 2013 & 2014 & 2015 & 2016 & 2017 \\
\hline 1 & 3190 & 5234 & 4595 & 4683 & 4883 & & & & & 195 \\
\hline 2 & & 204 & & & & & & & & 212 \\
\hline 3 & 160 & 38817 & 3319 & 28434 & 33705 & 32519 & 31182 & 26602 & 31469 & 2449 \\
\hline 4 & $40 \overline{4}$ & 14105 & $122 \overline{2}$ & 13319 & 15176 & 14461 & 13467 & 12081 & 14640 & $1185^{\circ}$ \\
\hline 5 & 36 & 2369 & $253 \overline{8}$ & 2562 & 2712 & 2728 & 2431 & 1908 & 2338 & 1669 \\
\hline 6 & 691 & 6759 & 6498 & 6284 & 6823 & 6535 & 5830 & 5312 & 8776 & 4771 \\
\hline 7 & 328 & 8192 & 8970 & 8521 & 8556 & 9405 & 9179 & 8156 & 9832 & 8326 \\
\hline 8 & 13 & 670 & 707 & & 775 & 724 & 595 & 409 & & 393 \\
\hline 9 & 5084 & 8732 & 7624 & 8341 & 9161 & 9223 & 8769 & 7500 & 8287 & 7335 \\
\hline 10 & 096 & 2002 & 1792 & 1626 & 1669 & 1955 & 1742 & 1445 & 30 & 1416 \\
\hline $11 \mathrm{~N}$ & 94 & 257 & 330 & 465 & 321 & 433 & 168 & 569 & 002 & 310 \\
\hline 12 & 1592 & 31880 & 2955 & 30278 & 33583 & 33610 & 33432 & 29744 & 31993 & 2997 \\
\hline 13 & 722 & 588 & $322 \overline{2}$ & 3766 & 3840 & 6710 & 5200 & 32 & 090 & 2679 \\
\hline 14 & 2510 & 42682 & 3942 & 40854 & 44769 & 45204 & 45674 & 41101 & 48010 & 4093 \\
\hline 15 & $532 \hat{8}$ & 12447 & $114 \overline{8}$ & 11305 & 12392 & 12367 & 11380 & 10441 & & 1011 \\
\hline 16 & 6790 & 12709 & $106 \overline{5}$ & 11567 & 13065 & 12250 & 11979 & 11234 & & 06 \\
\hline 17 & 6451 & 10725 & $953 \overline{7}$ & 10184 & 11573 & 11660 & 11865 & 10465 & 11645 & 9634 \\
\hline 18 & $303 \overline{3}$ & 63523 & $586 \overline{8}$ & $5842 \overline{7}$ & 63723 & $6349 \overline{7}$ & $6481 \overline{7}$ & $56413^{-}$ & $6211 \overline{8}$ & 5626 \\
\hline 19 & 4260 & 85357 & $818 \overline{9}$ & 79237 & 85969 & 87797 & 86728 & 75260 & 88482 & 7715 \\
\hline 20 & 1526 & 3056 & 2783 & 2396 & 2952 & 2131 & 2738 & 1930 & 2636 & $159 \overline{7}$ \\
\hline 21 & 1399 & 2105 & 1758 & 1464 & 2359 & 1776 & 2078 & 1783 & 1853 & 1133 \\
\hline 22 & 8228 & 15086 & 1341 & 12141 & 12544 & 11899 & 11926 & 10972 & 10653 & 9161 \\
\hline 23 & 6647 & 12386 & $127 \overline{6}$ & 10533 & 11642 & 11823 & 11538 & 10558 & 11799 & 1300 \\
\hline 24 & 1918 & 2342 & $210 \overline{4}$ & 2648 & 2869 & 3371 & 3603 & 3432 & 4074 & 2948 \\
\hline 25 & 2006 & 2854 & 2404 & 1948 & 2681 & 3069 & 3094 & 4249 & 2397 & 246 \\
\hline 26 & 1011 & 1210 & 871 & 612 & 1003 & 1254 & 1043 & & 4892 & 43 \\
\hline 27 & 1526 & 1991 & 2602 & 1535 & 2658 & 2318 & 2341 & 1948 & 2777 & 1537 \\
\hline 28 & 7604 & 11667 & 8226 & 83864 & 10839 & 80920 & 76915 & 67354 & 87605 & 655 \\
\hline
\end{tabular}


Table 2

ISO 9001 the number of the standard's incorporations by sectors cont.

\begin{tabular}{lrrrrrrrrrr} 
EA & $\mathbf{2 0 0 8}$ & $\mathbf{2 0 0 9}$ & $\mathbf{2 0 1 0}$ & $\mathbf{2 0 1 1}$ & $\mathbf{2 0 1 2}$ & $\mathbf{2 0 1 3}$ & $\mathbf{2 0 1 4}$ & $\mathbf{2 0 1 5}$ & $\mathbf{2 0 1 6}$ & $\mathbf{2 0 1 7}$ \\
29 & 46180 & 63015 & 53051 & 55961 & 70082 & 73167 & 73756 & 66975 & 79492 & 66463 \\
30 & 3437 & 4731 & 3499 & 3664 & 5496 & 5021 & 5045 & 4340 & 5398 & 3565 \\
31 & 24899 & 32286 & 22804 & 24846 & 31679 & 31490 & 30845 & 27053 & 30418 & 23948 \\
32 & 8571 & 13900 & 11057 & 11423 & 16445 & 16198 & 16469 & 15621 & 16532 & 12348 \\
33 & 12505 & 21410 & 18998 & 20467 & 24690 & 27229 & 28995 & 29162 & 35268 & 33664 \\
34 & 20761 & 35909 & 32726 & 31086 & 38160 & 38659 & 38694 & 36346 & 38396 & 36107 \\
35 & 41404 & 53116 & 41615 & 40303 & 54572 & 55602 & 57860 & 50696 & 54506 & 40122 \\
36 & 4911 & 7938 & 5399 & 6468 & 7428 & 8039 & 7732 & 6580 & 6058 & 4908 \\
37 & 16242 & 19689 & 14511 & 14141 & 19379 & 19713 & 20079 & 16657 & 17703 & 11270 \\
38 & 19712 & 21909 & 16278 & 19351 & 25036 & 26992 & 26243 & 22342 & 24320 & 15628 \\
39 & 8518 & 12748 & 7620 & 6987 & 10601 & 10240 & 11579 & 10017 & 10711 & 7843 \\
\hline Total & $\mathbf{5 5 0 0 7 6}$ & $\mathbf{8 9 4 1 3 3}$ & $\mathbf{7 6 0 2 4 3}$ & $\mathbf{7 6 6 7 7 8}$ & $\mathbf{9 1 1 5 6 4}$ & $\mathbf{8 9 5 3 6 3}$ & $\mathbf{8 9 2 4 9 1}$ & $\mathbf{7 9 2 1 4 5}$ & $\mathbf{9 2 1 7 6 0}$ & $\mathbf{7 4 6 2 0 4}$
\end{tabular}

Source: (The ISO Survey 1998-2017, Switzerland, 2018)

\section{CONCLUSION}

In comparison, the situation for global and European data in terms of sectors leading and incidentally incorporating the ISO 9001 is similar.

Both globally and in Europe, the leading sectors are as follows: Basic Metals \& Fabricated Metal Products; Construction; Electrical \& Optical Equipment; Wholesale \& Retail Trade; Repair of Motor Vehicles Motorcycles \& Personal \& Household Goods; Other Services. However, globally, slightly differently than in Europe, an important part is played by ISO 9001 incorporations in the following sectors Machinery \& Equipment and Rubber \& Plastic Products.

Meanwhile, Europe's Health \& Social Work sector, which is also a leading sector, attracts attention. On the other hand, incidental cases are visible both globally and in Europe and include such sectors as: Nuclear Fuel; Publishing Companies; Gas Supply; Manufacture of Coke \& Refined Petroleum Products. It is worth noting the small number of incorporations in Europe's Leather sector.

In consequence, it is possible to observe that for 39 sectors, 14 are sectors which feature the most ISO 9001 incorporations. These include the following sectors: Health \& Social Work; Education; Other Services; Engineering Services; Information Technology; Transport, Storage \& Communication; Wholesale \& Retail Trade; Repair of Motor Vehicles, Motorcycles \& Personal \& Household Goods; Construction; Electrical \& Optical Equipment; Machinery \& Equipment; Basic Metals \& Fabricated Metal Products; Rubber \& Plastic Products; Chemicals, Chemical Products \& Fibres and Food products, Beverages \& Tobacco. This results from the sectors' specificity. It also seems that companies used the ISO 9001 to establish a specific communication code which not only constitutes a basis for co-operation, but also facilitates compatibility between particular parts of the world that differ in many aspects. The least ISO 9001 incorporations take place in such countries as Nuclear Fuel and Publishing Companies. It is also worth mentioning the study's limitations. For European countries, detailed statistics of the number of ISO 9001 incorporations for particular industrial sectors are available for 2009-2014, which constitutes a certain study limitation. The lack of detailed data can result from the standard's modification of 2015. Many companies have 
incorporated the standard prior to 2015 due to concerns about changes, which can also be the cause of lack of data availability.

\section{REFERENCES}

Allur, E., Heras-Saizarbitoria, I., Casadesus, M., 2014. Internalization of ISO 9001: a longitudinal survey, Industrial Management \& Data Systems, 114(6), 872-885.

Briscoe, J.A., Fawcett, S.E., Todd, R.H., 2005. The implementation and impact of ISO 9000 among small manufacturing enterprises, Journal of Small Business Management, 43(3), 309-330.

Dick, G.P.M., Heras, I., Casadesus, M., 2008. Shedding light on causation between ISO 9001 and improved business performance, International Journal of Operations \& Production Management, 28(7-8), 687-708.

Franceschini, F., Galetto, M., Mastrogiacomo, L., 2018. ISO 9001 certification and failure risk: any relationship?, Total Quality Management \& Business Excellence, 29(11-12), 1279-1293.

Heras-Saizarbitoria, I., 2011. Internalization of ISO 9000: an exploratory study, Industrial Management \& Data Systems, 111(8-9), 1214-1237.

Hys, K., 2015. ISO/TS 16949 analysis of the current trends, Zarządzanie $i$ Finanse, Journal of Management and Finance, Copyright by Uniwersytet Gdański, 13(2), 37-45.

Karapetrovic, S., Casadesus F. M., Heras Saizarbitoria, I., 2010. What happened to the ISO 9000 lustre? An eight-year study, Total Quality Management \& Business Excellence, 21(3), 245-267.

Kim, D.Y., Jumar, V. and Jumar, U., 2011. A performance realization framework for implementing ISO 9000, International Journal of Quality \& Reliability Management, 28(4), 383-404.

Koc, T., 2007. The impact of ISO 9000 quality management systems on manufacturing, Journal of Materials Processing Technology, 186(1-3), 207-213.

Marin, M.L., Ruiz-Olalla, C.M., 2011. ISO 9000:2000 certification and business results, International Journal of Quality \& Reliability Management, 28(6), 649.

Rusjan, B., Alič, M., 2010. Capitalising on ISO 9001 benefits for strategic results, International Journal of Quality \& Reliability Management, 27(7), 756.

Sampaio, P., Saraiva, P. and Rodrigues, A.G., 2009. ISO 9001 certification research: questions, answers and approaches, International Journal of Quality \& Reliability Management, 26(1), 38-58.

The ISO Survey 1998-2017, 2018. Data per country and sector - 1998 to 2017, ISO: International Organization for Standardization, Switzerland, available at: www.iso.org/iso/iso-survey.html (accessed July 1, 2018).

Terziovski, M., Power, D., Sohal, A.S., 2003. The longitudinal effects of the ISO 9000 certification process on business performance, European Journal of Operational Research, 146(3), 580-595. 